\title{
GENOCIDE AS SOCIAL PRACTICE. REORGANIZING SOCIETY UNDER THE NAZIS AND ARGENTINA'S MILITARY JUNTAS. (DANIEL FEIERSTEIN, RUTGERS UNIVERSITY PRESS, 2014)
}

\author{
MAXIMILIANO E. KORSTANJE ${ }^{l}$
}

As one of most important scholars dedicated to the theme of genocide in Argentina, Daniel Feierstein in his recent book discusses critically the need to construct a conceptual framework to expand the current understanding of genocide, as well as to explain how it operates in a context of instability and uncertainty. Two of the guiding themes that are addressed throughout this pungent book are to what extent the Nazi regime may be equated to the Juntas that appeared in Argentina, and what are the effects of memory in political life.

Readers who wish to open Genocide as a Social Practice will find a major dilemma discussed in the introductory chapters: should a new definition of genocide be created to incorporate the ideas and practices of the bloody dictatorship which occurred in 1976 and 1982 in Argentina, and can this dictatorship be ethically and legally compared to Nazism in Germany?

The introductory chapters remind us that genocide was a neologism coined by Lemkin which became a legal term according to the United Nations in 1948 to describe a deliberate attempt to systematically destroy an entire population because of their ethnic, racial or religious characteristics. This definition means that the term can only with great difficulty be extrapolated to the Latin American situation. In its original draft, this project acknowledges that the "Argentine genocide" does not correspond to the classic definition of ethnic cleansing in view of the fact that the military-forces involved were moved by ideological goals. From its onset, the declaration refuses to consider ideology as a motive for extermination or genocide. Based on the doctrine of

1 Maximiliano E. Korstanje is professor at the University of Palermo, Buenos Aires; e-mail: maxikorstanje@arnet.com.ar 
national security, army-forces searched, jailed and exterminated any agents who could represent a centre of infection for social scaffolding. Alluding to the metaphor of disciplinary power in foucaultian terms, Feierstein runs the risk of re-opening the discussion about whether to reconsider the meaning given to normalcy and pathology. Modern institutions have developed new economies to control certain bodies. Visualizing skills and bodies as a form of control alludes to meeting the needs of individuality, but the paradox is that at the same time it re-constructs a non-egalitarian form of power. Normalcy is based on the production of pathology, and vice-versa.

Unless otherwise resolved, the Juntas developed disciplinary practices of extreme violence based on the ideology of the victims, not their race. Supported by extreme, left-wing Catholic sectors, the state envisaged Marxist ideology to be a significant threat that required defeating. This pathological form of thought became rooted at the core of society. The struggle against "domestic subversion" became a priority for the Argentine government. The 'red-scare' typically presented Juntas with a great quandary; how should they treat prisoners?

In his efforts to adjust the concept of crime towards the jurisprudence of genocide, Feierstein is required to forge a new definition of genocide which goes beyond the boundaries of that formulated by United Nation a half century ago. Most certainly, this work shows the importance of formulating a new definition of genocide by adding political violence as a criterion for the obliteration of peoples. The declaration of the UN in 1948, in fact, did not allow that one reason for genocide may very well be to apply in extremis the ideology of the victims themselves. For this reason it is necessary not only to reopen the still hot debate about the tactics and techniques the Juntas used to keep order, but also to re-examine how these types of events are repressed or memorized.

In opposition to other specialized perspectives, Feierstein brilliantly suggests that any "genocide practice" is embedded within a much broader process that never ends. An act of genocide refers not only to practices of violence but also to meanings that are conferred to understanding such events. What is highly interesting to consider is why Feierstein does not seem to be in agreement with the classical definition of genocide.

He would reply with the observation that if the law supports the proposition that egalitarian conditions to every citizen be considered equal, excluding some victims in the declaration according to their characteristics does not correspond with the nature of Roman rights. Jurisprudence after WWII evaluated and contemplated recognised that some states would not accept the UN's declaration in view of their own territorial disputes with other 
minorities within their territories. Although the United Nations was formed to prevent a repeat of the holocaust, the declarations it produced failed to control the crimes of nation-states against their own populations. In addition, the declaration recreates significant legal asymmetry between citizens. This final document not only contrasts bases of legality (since the crime should not be valorised by the characteristics of its victims), but also engenders the existence of a hierarchy of potential victims.

The paradoxical situation rests on the idea that nation-states have reserved the right to a monopoly of violence that can be exerted on their respective populations - even minorities or vulnerable civilians. Needless to say, in an age when crimes were committed through commitment to ideologies, a law which determined the protection of victims in accordance with their racial character was out of context. If crimes that are committed against civilians because of their religion (a system of ideas) are banned, then why was the concept of ideology excluded from the declaration?

With this in mind, Feierstein leads the point of discussion to another place. The torture, forced disappearances and acts of violence planned by the Juntas in Argentina, Feierstein states, should be typified as acts of genocide. Like the Nazis, the Argentine military deprived persons of their rights through the articulation of diverse mechanisms which ranged from psychological torture to death. Although they looked to avoid any charge that their crimes were ethically motivated, it is important to see that this problem is based on the dichotomy between being and doing.

In Argentina, potential victims were selected because of their supposed participation in civilian armies. They were not killed because they belonged to a certain race or ethnicity or because of any biological differences. Feierstein clarifies that there are commonalities to both processes, such as the reduction of others according to "degenerative logic". Like Nazism, the Juntas developed a disciplinary allegory to promote the story that the population (the "insurgents") were a cancer, a degenerative agent which should be extirpated for the wellbeing of the wider community. Their success in promoting the idea of the need to maintain the purity of ones' own species corresponded with the success they had in manipulating and assassinating systematically those 'germs' that had a dysfunctional effect on the whole. The 'character' or temper of their prisoners (in Argentina as well as in Germany) was undoubtedly irreversible. Once captured, imprisoned and tortured inmates have no opportunity to change their ideology or compromise or to abandon the fight. Genocide, as a form of discipline, makes all men egalitarian - to their deaths.

The disciplinary treatment for Jews in concentration camps was the 
same applied to Argentine insurgents. Defined as technology of power, the practice of genocide was aimed at reorganizing social life. To expand the new ideology, the old one required eradicating, along with former practices in the public sphere. The main thesis of this valuable book is in the recognition that genocide resorts to establishing new discontinuities as a "re-organizing practice". A return to democracy after a dictatorship collapses not only fails to recover memory but also imposes a new doctrine. Based on the assumption that military forces and militias fought a war, the theory of two demons constructs a hegemonic discourse that orients itself around blaming the victim. At the end, though, and only to some extent, Feierstein has success in resolving the limitations which have historically surfaced in specialised literature by comparing the Nazi regime with the Juntas. However insofar as the practice of extreme violence dissuades witnesses and the rest of population from accepting policies that would otherwise would accepted, some conceptual problems arise. In his effort to demonstrate the hypotheses stated in first chapters of the book, Feierstein may be putting the horse before the cart, and even misunderstanding genocide as violence.

First and foremost, the loyalties of civilians to Adolf Hitler and Jorge Rafael Videla were multifarious. Feierstein does not clearly appreciate the conceptual difference between a totalitarian and an authoritarian government. While the former subordinates all private life to the public space (which is monopolized by a one sided-perspective) the latter signals trouble as a tool to control private lives. The inability of the Juntas to successfully manage the economy and politics resulted in a significant failure to exert total control over the civility, which never adopted the mandate of the Juntas or the view of extreme insurgents. In the case of Germany, however, devotion to the leader was complete to the extent that it allowed a total war to be conducted beyond the boundaries of the nation. As F. Timmermann (2008) put it, the Latino American citizen withdraws from the public space when pressed by the violence of state. This process facilitated the adoption of neoliberal policies a couple of decades later due to the indifference of worker unions. The inability of lay-citizens to prevent violence determined their lack of interest in politics.

In view of this, the second difference consists in the total commitment of army forces with the cause of the Junta. From soldiers to generals, militias in Argentina believed they were fighting against a great evil. Their victory would represent the harmonization of nation and home. John Kekes is not wrong when says "while Argentine soldiers were fully committed in their mythical crusade, Nazis preferred not to be in contact with camp's inmates". Observations like this led Hanna Arendt to coin a neologism, "the banality of evil", to express cynical indifference to another's fate as a subject of 
ethics. The lack of critical thought which characterized the outlook of many Nazis stands in opposition to that of the Argentines. Furthermore, if Hitler was democratically elected by popular vote, Videla took power by replacing the constitutional rights, the senate and other democratic institutions with a new form of authoritarian government. Nonetheless, the authoritarian view in politics was functional economic liberalism. Employed to disintegrate the struggles of the workers' unions, violence destroyed the will to ask for international help from abroad. This text does not evaluate with clarity the pervasive role of the major financial powers (US and Europe) in issuing credit to non-democratic governments at the time as they denounced Videla's regime for violating human rights. The same tactics persisted over the following decades, generating financial dependency between the centre and peripheral nations.

Feierstein ignores the tragic outcome of subversion in Argentina before the coup d'état. By 1974 almost 200 political crimes had been perpetrated by civil armies; this number had risen to 860 by 1975 . During 1973-1976, the 1358 deaths that had resulted through terrorist attacks had taken the lives of 677 civilians, 180 policemen and 66 military officers. By trivializing the degree of violence exerted by the different actors, Feierstein imposes the same biased argument he criticizes the UN for making in its declaration. If the document determines that crimes of genocide are defined by the characteristics of its victims, Feierstein assumes that the responsibility of state and civilians depends on their strength and not on the crimes they committed. Even if the Juntas conducted disgusting crimes against citizens without being legally bought to account, it is important to understand the ideology they employed which led to the sentiment that they were superior to civilian governments. Historically, in Latin America military forces have reserved the right to intervene in politics directly or indirectly when civilians cannot keep order in their homeland (Kekes, 1985).

Last but not least, the partial view of Feierstein regarding memory (the trivialization of the violence exerted by civil militias or insurgents on other targets) does not allow the formulation of an accurate, all-encompassing model of human rights. The conceptual limitation of human rights, as they are delineated by author, refers to the following axiom.

Whenever human rights are preserved as universal values we meet with ethical problems concerning the autonomy of cultures and other nations. We start from the premise that after the XX century almost all genocides were committed by states which should supposedly have protected victims. The concept of autonomy is not a category of modernity, as Feierstein obstinately insists, but the legal exception to guarantees of human rights. Despite the 
international denunciation of the US of systematic human rights violations, this stance indicates adherence to the principle of self-determination to avoid any criticism from external nations. The same happened in Argentina where the government imposed a biased set of human rights to encourage restrictive policies that limit democracy and free speech.

To put it bluntly, rights and duties are not the only key factors of a legal system, but they offset the benefits and costs of keeping societal order. Legally, if human rights are thought of as universal and applicable to all nations, we need to think of the role of the common duty to uphold them as well. Homogenizing of all duty in this regard concentrates authority in one state. The loyalties of citizenry to their respective states are based on respect for rights. If a group does not respect common rights, the state employs the violence necessary to intervene, perhaps in international affairs. When we re-state that human rights are not local but universal, we must accept that a third police state should emerge. This new powerful state will grant safety in the periphery while the centre remains untouched. Having the strength to intervene in the politics of other nations exempts the third power of being charged with having a policy of intervention. Philosophically speaking, the adoption of human rights as a universal value paves the way for the advent of the dictatorship of human rights. Moreover, this book does not properly examine the roots of terrorism (as a dialectic of hate when an state employs torture as instrument of dissuasion in view of its inability to otherwise keep order, or in the form of a group of insurgents using violence to vindicate its claims). The surprise factor, combined with fear and extortion, means that terrorism is very difficult to understand. Terrorism is rooted in the same logic as democracy (Korstanje, 2013).

Let me explain that, in the tragedy of the disappeared, those who were tortured did not chose their destiny. They were forced in a context of violence to become anonymous and fall out of the reach of legal jurisprudence. In these types of events, the paradox is that the state systematically kills civilians who are supposedly in its custody. Anthropologically, the problem with disappearance is that it signals the lack of a body. Human existence is determined by the presence of death. As a souvenir, the existence of a body serves in funerary rites and rituals to avoid the disintegration of community. Ancestors are mediators between this world and the hereafter and are enigmas to the human existence. In the context of disasters such as those described, people may understand that, after all, they survived. Their mourning and loss are not in vain because they are still alive. To understand what happened, survivors weave a narrative based on their exemplarity and superiority. To the question 'why did we survive?' emerges the response 'because of our moral 
strength, our civic or cultural superiority'. This type of reaction in sedentary societies creates positive and negative consequences. On the one hand, it facilitates the process of recovery for survivors (resilience) as well as offering psychological therapy for their losses. On the other hand, if these mechanisms of resilience are replicated in the long-term, or become ideologized into the apparatus of the state, they may lead to over-valorisation of the survivor's assets. As a result, expressions of nationalism and chauvinism may emerge to create a biased version of memory, silencing the real reasons for tragedy. Since the problem is not tackled, the tragedy will come back in the near future. If we think of survivors of dictatorship as heroes, we will never understand the situation. It is important not to lose sight of the fact that, whenever political ideology and memory are linked, new hegemonic forms of power surface. The concept of exeptionalism in the survivor's mind, if not corrected, may lead to a restricted view of reality because the self thinks that happiness may be reached through the (re)introduction of suffering.

\section{REFERENCES}

Arendt, H. (1994). Eichmann in Jerusalem: a report on the banality of evil (p. 456910). NY, Penguin.

Kekes, J. (1985) The Roots of Evil. Ithaca, Cornell University Press.

Korstanje, M. E. (2013). "Preemption and Terrorism. When the Future Governs". Cultura, 10(1), 167-184.

Timmermann, F (2008) Violencia de Texto, Violencia de contexto. Santiago, Ediciones UCSH. 